\title{
The Labour of Transformation and Circuits of Value 'around' Reality Television
}

\section{Beverley Skeggs and Helen Wood}

for Continuum: Journal of Media and Cultural Studies vol 22. no 4. August 2008. pp. 559-572 (ISSN: 1030-4312)

see http:/www.tandf.co.uk/journals

\begin{abstract}
Drawing on recent research from a project which included both textual and audience research, this paper will explore the involvement of women viewers with 'reality' TV as 'circuits of value'. These relationships cannot be adequately described as deconstructions of representations as in a text-reader framework of media theory. Rather, we examine these relationships as an extended social realm, whereby the immanent structure of reality television generates emotional connections to the labouring undertaken by participants on the programmes. 'Reality' television develops different traditions of women's genres from melodrama, magazines to lifestyle television, it drawing attention to those who need transformation. By promoting different forms of women's emotional, appearance and domestic labour, it parallels broader political shifts to an 'affective economy'. Rather than these texts producing wholly divisive moral reactions in viewers, we noticed how our audience participants assessed the forms of labour performed through their different classed resources, made judgements through pursuing connections with their own lives, and ultimately tended to value care over condemnation.
\end{abstract}

\section{Introduction: immediacy and intimacy}

The current swathe of 'reality' television engulfing our television channels could be seen as the medium ultimately fulfilling its own technical potential. Television as a domestic medium reorients the household space it physically inhabits into the space it covers or represents on television. What Lang and Lang call 'the unique perspective of television' (1982, cited in Scannell 2001) refers to the way in which television's claims to liveness and immediacy create a sense of spatially and temporally 'being there', an experience which a phenomenologist like Paddy Scannell would describe as an 'authentic' publicness through which we have direct access to the witnessing of events 'out there', or a kind of 'proximity without presence' (Fleisch 1987). In many ways, therefore, 'reality' television represents some of the triumphs of the medium. However edited, scripted or formatted, 'reality' television presents the audience with the tension over an impossibly knowable 'what will happen next', making us part of the unravelling of the 'real' before our eyes. Whilst the staging of events on 'reality' television complicates any ontological claim to the 'real', it can make a claim to the 'actual' - the camera tells us this 'actually' happened as a response to an unscripted, if contrived, actual situation. According to Kavka and West (2004), the etymological genealogy of 'actual' is related to a temporal sense of 'now', rather than an ontological claim to truth, through which 'reality' television constructs a new sense of 'presentness', arguing that 'reality' television 'is curiously 
appropriate to its medium because of the way it manipulates time as a guarantor of both realness and social intimacy' (2004:136). This is a process set in motion by the potential of the medium: 'The actuality strengthens the effect of immediacy; immediacy strengthens the effect of social community; and the community creates a sense of intimacy with performers' (Kavka and West 2004:141).

\section{Extending Intimacy: Domesticity and Moral Responsibility}

What then are the implications of this special claim to intimacy produced within 'reality' television? The realm of intimacy is one traditionally associated with the feminine private sphere, but various commentators have marked out how public worlds, institutions and market forces have marshalled the intimate terrain into public spaces for the operation of power, using it to reinforce arguments of 'normalcy' against the ruptures of social and cultural tensions. Lauren Berlant (2000) tells us 'intimacy also involves an aspiration for a narrative about something shared, a story about oneself and others...set within zones of familiarity and comfort: friendship, the couple, and the family form, animated by expressive and emancipating kinds of love' (Berlant 2000). It seems clear that stories told in various forms of 'reality' television contribute to the tide of ways in which questions of intimacy are transmuted through, for example, the rise of the therapy industry, talk shows and pseudo-psychological advice espoused in women's magazines. Yet often the questions asked about 'reality' television as a genre fail to adequately account for how it sits adjacent to those forms, or explain how these histories have associated connections to the terrain of emotional labour. Eva Illouz (1997) maintains the 'transformation of intimacy' calls for an extension of notions such as domination and capital to domains hitherto out of reach. Moreover, Patricia Clough (2003) proposes that the promise of normalization is no longer simply trusted to the family, kin groups and other institutions of civil society: it is also a matter of investment in and regulation of market-driven circulation of affect: control accompanies the shift in capitalist accumulation to the domain of affect and attention.

'Reality' television, by sensationalizing women's domestic labour and emotional management of relationships, displays the new ways in which capital extends into the 'private', in which capital is engaged in the socialization of affective capacities. The space and practice of intimacy becomes like other social goods and exchange-values that are socially distributed and allocated. Miriam Glucksmann (2005) has for a long time insisted on the importance of domestic and emotional labour to the maintenance of the economy. She uses 'the social organisation of labour' to name total social reproduction. But we now see increased attention paid to how the economy and economics have to move beyond the limited sphere of production towards the totality of social life -1 , or what Marx (1973) called general productive power, in which activities assumed to lie outside of capitalism are subsumed within it. Eeva Jokineen (fc) refers to this process as the 'fourth shift', a temporal moment in labour relations in which the borderline between work and home becomes obscure and dissolved. In the fourth shift, the core of creating and accumulating wealth shifts from material goods to immaterial ones, in which knowledge, education, communication, caring and taking care of the chain of services - all kinds of domestic management - are central, and the paradigmatic form of new work is domestic work.2 It is the visualisation of this fourth shifts, to affective, domestic, emotional and affective labour on 'television' and the process of subsumption by which value is extracted from intimacy, we address by utilising some of the data from our empirical research project on 'reality' television and women audiences. We are concerned with how 'reality' television contributes to the transmission, legitimation and promotion of the distribution of unequal resources and domination though its emphasis on intimacy in 
the location of domesticity. And in particular, how domestic and emotional labour becomes the mechanisms by which bad subjects are subject to transformation.

In the move to an affective economy, the establishment of moral value becomes more transparent, as caring for (labour) and caring about (affection) are made explicit as responsibilities to be performed. 'Reality' television relies upon attaching signs of value, making good and bad behaviour specific to practices, bodies and people.

Some forms of 'reality' and transformation lifestyle television (Wife Swap, Supernanny, What Not to Wear, Honey We're Killing the Kids) for example, by sensationalizing women's domestic labour and the emotional management of relationships, foreground the ways in which capital is engaged in the socialization of affective capacities. The space and practice of intimacy becomes like other social goods and exchange-values that are socially distributed, allocatedand mediated.

Yet this subsumption is able to utilise a long historical tradition of making women the visible bearers of moral value. Davidoff and Hall (1987) note how in the 1840s a culture of domesticity was established, promoted by middle-class women, who were expected to operate as the relay mechanisms of manners and morality to pass on their influence to others (often in the early traditions of social work) in 'the minutiae of everyday life, their personal behaviour, dress and language became their arena to judge and be judged in' (p.398). During the twentieth century responsibility was also entrusted to working class women (see David 1980), but this extension of responsibility also brought with it increased surveillance, as if working-class women could never be fully trusted.

Mary Beth Haralovich (1992) documents how 1950s sit-coms detailed female (often maternal) failure, re-positioning domesticity from a practice in which pleasure was previously taken, to one in which women clearly 'need to try harder'. This shift brought into vision a different object: from the middle-class 'polite and proper' family to the dysfunctional working class family. By extension, what we see now with 'reality' television is the obsession with domestic failure and emotional management, in which responsibility for self and family development and control is separated into its constituent parts (cleaning, caring, education, eating, manners) and subjected to surveillance and judged accordingly. Middle-class practices are presented as the standard to be achieved regardless of the necessary resources required to achieve them. By repeatedly distinguishing, defining and attributing moral value to specific intimate practices, 'reality' television (like its predecessors, etiquette manuals, social work interventions, women's magazines and soap operas) makes the schema of moral value apparent as it identifies people in need of transformation, predominantly working class participants. Our research project therefore attempts to unpick exactly how moral value circulates around reality television's intimate excess.

\section{Audience Research Project: 'Making Class and the Self'}

Our research, funded by the ESRC 'Making Class and Self Through Televised Ethical Scenarios' (Res-148-25-0040), began with a detailed textual analysis of ten reality-style television series concerned with self-transformation in an attempt to capture a critical period on British television in the period 2004-2005. ${ }^{3}$ We used the generic term 'reality TV', to explore the increased use of working-class women to display the performance of different aspects of self-work. ${ }^{4}$ We examined how such a shift to self-representation challenges existing paradigms of representation. Since our study began, the range of formats available has multiplied, and the usefulness of the term has been questioned (Holmes and Jermyn, 2004). There is considerable mileage in textual enquiries into the distinctions between types and sub-genres of 
reality television, however, using the phrase 'reality TV' with our audiences mobilised conversations about its generic tendencies. Whilst we generated data on particular programmes, we were also able to compare parallel observations about distinct formats, some of which are explored in this chapter.

In addition to our textual analysis we interviewed, watched 'reality' television and conducted focus groups with forty women, middle and working class, white, Black and South Asian, settled and recent residents from four areas in South London. We gained access to four friendship groups through key informants. The interviews provided information on how the women watched and used television and how it fitted into their lives more generally. We developed Helen Wood's (2007) 'text-inaction' method to explore the viewing experience itself, watching a self-selected 'reality' programme (from our range of ten) with participants (and sometimes their friends) and recording their immediate reactions alongside the television text. Finally, we convened focus groups taking up key themes from our interviews in order explore how group opinions of reality television might mobilise around the popular public debates circulating at the time.

Before we get to some of our findings, let us locate some useful precedents in audience research that have been concerned with the way viewers use strategies of personal identification to interpret television texts. Numerous studies have suggested that proximity to the experience represented in the media shapes the types of responses produced. This has been described as a 'referential viewing mode' where audiences make fiction relevant to their real lives (Liebes and Katz,1990); it has also been related to viewers' establishment of 'para-social' relationships with television characters (Hobson, 1980; Livingstone, 1990); some studies often describe the inextricable entwining of stories about television texts with personal experiences (Hobson 1991; Press, 1991; Engel-Manga, 2003), and one study theorises the phenomena as a complex process of 'positioning the self' (Livingstone, 1994). Audience research has therefore repeatedly highlighted the fact that there are moments when viewers cannot fail to connect to what is happening on the screen as it resonates with and repeats their own experiences. But to incorporate this aspect of viewing into the more traditional model of 'decoding representations' might elude an analysis of the emotional and experiential aspects of television's intimacy. Wood's (2005) (rep later where more significant)research on talk television shows how viewers regularly talk back to television as if in conversation, through interlocutions which weave the people, incidents and problems on television with their own lives. This demonstrates a complex interaction between TV texts and subjectivity which is more dynamic than the relationship implied through the analogy of text-reader relations. We want to take some of these observations further, generated through our understanding of the intimate and immanent nature of 'reality TV' discussed above, to explore the genre's relationship with viewers as a 'mediated social/public realm' (Biressi and Nunn, 2004).

Speculating about the experience of watching 'reality' television, Justin Lewis (2004) suggests that we make sets of judgements through operating with two discrete sets of criteria: the experience of our immediate environment, and the broader symbolic reality of the world beyond it, where, if we are unable to make judgements in terms of our immediate experience, we make them in terms of our understanding of the codes and conventions of verisimilitude ('realness'), genre, characterisation. Often, 'reality' television's particular verisimilitude is related to its relationship to time and the 'actual' as described above, and also through mise-en-scene (i.e. filmic framing or composition) which makes use of familiar settings such as kitchens, gardens, living rooms, etc. Jon Dovey suggests that the increased use of the first person across new factual formats on television might invoke a different type of relationship between text 
and viewer: 'The particular rhetorical structures whereby texts make generalised meaning through specific representations are of less importance than the overall interactive relationships between audiences and texts that constitute public discourse space' (2000:159). Parallels can be drawn with the work of film theorist Vivian Sobchack (1992; 1999) whose phenomenology of film asks us to move beyond conceptualising film as an object of vision, towards accepting film as a concrete experience of the viewer. Film thus becomes open to dialogic interpretation as a sensuous experience, rather than conceptualised or cognised through conventional sign systems.

\section{The significance of 'labour'}

Through the emphasis on domesticity, relationships and the family as sites for inspection and transformation 'reality' television enables us to identify the aspects of emotional labour that generated viewers' interest. The previous invisibility of emotional and affective labour, once hidden and unacknowledged within the private sphere, is now made perfectly visible on reality television, particular in the case of reality shows centred around transforming selfhood and lifestyle. In different ways our participants regularly recognized the labour required for the requisite transformation to take place. For example the labour of femininity, made explicit on programmes like What Not To Wear through the amount of effort, skill and knowledge required, was recognised precisely as labour and not as natural and inevitable to an essential femininity. Conversations made with the programme in the text-in-action sessions often challenged the unrealistic standards promoted:

As Michelle responds to What Not to Wear:

Yeah, yeah. And you think... they forget that normal women have just got to go out and go to work and sort the kids out, and you know that does stuff your dresses up a bit.

Whilst Nicola suggests:

Remember how much hard work it is to look good all the time?

Lucy, here, group is 'talking back' to the fashion makeover show, What not to Wear:

\begin{tabular}{|c|c|c|}
\hline $\begin{array}{l}\text { Audio } \\
\text { Cue }\end{array}$ & Television text & Participant responses \\
\hline 02.23 & $\begin{array}{l}\text { Presenter Trinny (introducing } \\
\text { potential participants):... the } \\
\text { main offenders for closer } \\
\text { inspection }\end{array}$ & $\begin{array}{l}\text { Lucy: I bet they have got a nanny. } \\
\text { Bev: Yeah? } \\
\text { Lucy: I bet they have. I bet they have got } \\
\text { a nanny and it's all very well isn't it? }\end{array}$ \\
\hline 04.27 & $\begin{array}{l}\text { Trinny (on mothering): There } \\
\text { are all those juggling acts that } \\
\text { are really tough }\end{array}$ & $\begin{array}{l}\text { Lucy: Oh I think it's true but...But I think } \\
\text { that it's true but I don't think people want } \\
\text { to hear it from some stuck up posh bird } \\
\text { with a nanny. Do you know what I mean }\end{array}$ \\
\hline 07.13 & $\begin{array}{l}\text { Presenter Susannah: it's } \\
\text { Sarah, a mother of triplets who } \\
\text { not surprisingly }\end{array}$ & Lucy: triplets?! \\
\hline 07.19 & $\begin{array}{l}\text { Trinny: because they have } \\
\text { triplets }\end{array}$ & $\begin{array}{l}\text { Lucy: and no nanny. } \\
\text { Bev: mmm? } \\
\text { Lucy: and no nanny }\end{array}$ \\
\hline 07.45 & Trinny: three kids at 23 & \\
\hline
\end{tabular}




\begin{tabular}{|l|l|l|}
\hline 07.57 & $\begin{array}{l}\text { Susannah: ...drab, dull, } \\
\text { uninteresting woman }\end{array}$ & $\begin{array}{l}\text { Lucy [shouting]: no! you're exhausted, you } \\
\text { have got three kids }\end{array}$ \\
\hline
\end{tabular}

Lucy assesses the advice of make-over experts Trinny and Susannah in terms of different social location, but also the presumed labour attached to that position. She begins by suggesting the conditions for childcare between the experts and participants are radically different, which leads her to de-authorise the experts in specific class terms as, 'stuck up posh birds'. That the television participant has triplets makes Lucy, as a mother, even more sympathetic and protective of her, hence the strong response, shouting at the television 'experts' in a direct challenge to their assessment and authority. In a later section she is more willing momentarily to listen to their advice:

\begin{tabular}{|l|l|l|}
\hline 33.16 & $\begin{array}{l}\text { Suzannah: Now we are } \\
\text { suggesting clothes } \\
\text { which are practical by } \\
\text { being in a pattern } \\
\text { that'll cover up sick, a } \\
\text { bit of tomato ketchup... }\end{array}$ & Lucy: [laughs] that is quite good. \\
\hline 34.01 & $\begin{array}{l}\text { Participant: I can't } \\
\text { imagine I would ever } \\
\text { wear that. I like the } \\
\text { style but the whole } \\
\text { colour }\end{array}$ & $\begin{array}{l}\text { Lucy: Where is she going to wear that though? } \\
\text { She has got triplets? Where exactly? You know, } \\
\text { once a year to her husband's Christmas do and its } \\
\text { not going to hide sick is it? }\end{array}$ \\
\hline $\begin{array}{l}\text { Trinny: If you come } \\
\text { back in the same } \\
\text { clothes you are wearing } \\
\text { now I will personally } \\
\text { strangle you. You have } \\
£ 2,000 .\end{array}$ & $\begin{array}{l}\text { Lucy: She doesn't get it though does she? } \\
\text { [reference to Trinny] why women dress like that, } \\
\text { it's practicality, you want stuff that washes and } \\
\text { dries quick. You want stuff that maybe doesn't } \\
\text { need ironing. I have got lovely dresses, I don't } \\
\text { wear them to school because I would get snotted } \\
\text { on and you know I am getting up and down off the } \\
\text { floor and it...because I don't want to be hand- } \\
\text { washing and ironing and stuff, you know you have } \\
\text { got enough to do. } \\
\text { Bev: exactly } \\
\text { Lucy: they should be finding them nice stuff that's } \\
\text { easy care and it doesn't seem to be. }\end{array}$ \\
\hline
\end{tabular}

Lucy begins to think that Trinny understands the issue of clothing in relation to childcare, but then realises as the programme develops, that the speech of the experts is different to their action. Their advice is impractical which leads them to criticise the participant when it is not put into practice. The failure of the 'experts' to understand the labour of different women's lives informs all of Lucy's responses.

What is important to note is that Lucy does not address the programme as if 'deconstructing' a textual representation of the characters as such, but is involved in a dialogic relationship with the text (see Wood, 2007; 2008) potentially experienced more like an extended social realm. Her interactive engagement with the television show in question is governed by the actuality of the setting and the selfrepresentation of a 'real' mother. Thus, Lucy is immanently placing herself as adjudicator of this advice for her own life as well as that of the television participants, locating her self physically within the action: 'I don't want to be hand-washing etc'. We suggest that it is the focus on domestic labour and the labour of femininity that generates this connection, a gendered connection that also brings class relations into 
the conversation to assess authority (as seen in the dismissal of Trinny and Susannah as 'stuck up posh birds'). These types of responses were frequent in our data, where these programmes provoke recognition of the different types of labour and of the actual energy expended in the labour of femininity.

The connection to the participants through labour is also generated through an assessment of the extent of their efforts. The actual visual performance of labour, that is often central to the dramatic action on 'reality' television, was significant to the ways viewers assessed participants. An appreciation of those who 'just get on with it' was a regular theme, and a central criterion for judgment. For example our Addington group (white working class from South East London) debate the merits of Jordan ${ }^{5}$ on I'm a Celebrity Get Me Out of Here':

Nicola: I always liked Jordan.

Joan: I didn't.

Vik: I didn't either.

Joan: I didn't like her.

Mel: Well not that I didn't like her, I didn't know her, I didn't know anything about her really just what l'd seen on the telly and I think she's got a bad, not a bad name but she adds up, well she did. I really did hear her talking and that, she had quite a lot to talk about, it weren't just about herself. She's quite a funny person as well. You think a person like her, 'cause she's got money and that and she's going to be spoilt: 'me me me', but she weren't. She was like--, she did the tasks and that, she didn't think, "no I ain't doing that", like some of them said, "I'm not going to do that," and she just got on and did it. Joan: She had to prove herself and she did.

Our participants' perception of a woman often vilified in the British media transforms after they see her making an effort and not complaining on the programme. For Joan this means she has 'proven herself' to have value in their eyes. Jordan's uncomplaining labour enables a connection to be made by the women to her performance, and using the same value system they apply to themselves to assess the celebrity.

'Getting on with it' is valued and there is a good deal of discussion across our data about the value attached to people 'coping', for example:

Just to see how other parents are coping like with difficult children and then seeing what her method is in terms of coping with that. (Kathy, Brockley group)

A figure who achieved celebrity status through the programme Wife Swap is Lizzie Bardsley from the first series. She was unapolagetically loud, clearly working class, and engages in a spectacular row with the other wife. Rather than drawing upon the dominant portrayal of Lizzie in the press afterwards, ${ }^{6}$ Sharon and Michelle from Addington describe the value they saw in watching how she 'coped' with her life.

Bev: So you remember Lizzy?

Sharon: Just how she managed to cope with what she had. She had loads of children didn't she?

Bev: Yeah, eight children.

Michelle: And she used to have to do all the dinners and I don't know, I couldn't do it myself. 
Similarly Michelle from Addington locates the struggle on television within context of the 'real world' and again sees the incongruency between the 'professional' role of the expert and the 'coping' role of mother on Supernanny:

Yeah put it in the real world, I mean you are the mum that's left on their own and you're trying to cope with that and a hundred other things on top, it's not quite the same is it. 'Cos looking after a child as a nanny is completely different than looking after a child as a mother, completely different. But you can see its text-book theory. You know, it does work, it would work, but it's very hard to-.

Particularly for our working class participants where the labour of their own lives is lived through similar requirements, value is placed on indefatigability - a survival tactic that has a long history in working-class culture. For example, Paul Willis' (1977) discusses the working class values attached to the physicality and endurance of 'practical' manual labour. The television participants, celebrities or otherwise, are subject to the same judgments applied to themselves, enabling immanence and generating a dialogical effect. The way in which Michelle articulates her disagreement with experts through 'you are the mum...you're trying to cope' again registers an attempt to locate oneself within the narrative of the television text as an evocation of recognition and even co-presence. By speaking to and about participants, our viewers also seamlessly speak to and about themselves, which we suggest establishes a 'circuit of value'.

\section{Class, Value and 'authentic' modes of labour}

Whilst similar forms of attachments may well be found in audience responses to fiction, we suggest that the way in which the 'circuit of value' is established here is exacerbated by the consequences of self-representation and generic verisimilitude of reality TV. Viewers often draw a distinction between participants on reality operating as performers taking a part in a television text or event, and those valued as 'real' people inhabiting recognisable lifeworlds who are therefore subject to recognisable constraints. The working-class women in the study are media literate in terms of the staging and editing of television production, but at the same time they make connections to the 'real' through seeking out authentic experience. Therefore, recognition and assessment of effort also directly leads to viewers to make judgements about the authenticity of the participants, for example:

Vik: The ones you can tell like when they're acting, you can see when they're acting for the camera and you can see the other ones that ain't, that are just getting on with it.

Our findings replicate those of Hill (2005) and Jones (2003) whereby the pleasures of viewing reality television are generated in the dramatic 'breakthrough' moments when participants 'show their real face'. Audiences are described as valuing authentic displays of emotion in the otherwise inauthentic arena of reality television. But in our data, particularly that drawn from working class participants, that moment of revelation is directly attached to forms of labour. For participants to be acting for the camera, is a distraction from the effort required and distances our viewers in terms of the attachments they might make.

This was very different from the responses generated by our middle-class participants in our Forest Hill focus group. Their group reading was created through offering more abstract and critical readings of texts and their construction, rather than in terms of immanent attachments. They were concerned with a broader cultural debate about celebrity culture and in particular with a perceived lack of labour 
involved in 'making it': Liselle: 'I think we start to think that you don't have to work hard to get things and don't have to, it's like the kids who just want to be famous', and, Orlaine: 'About how people get famous and rich for not having any skills any more'. Effort and labour are directly connected to the rewards of paid work reliant on legitimate skills and education thereby reproducing a formulation of labour connected to a different value system, which for them cannot be replicated in the television format. (Elsewhere we describe how the middle-class women in our study were often able to distance themselves from the 'reality' TV by using their cultural capital to articulate quite sophisticated discussions of contemporary culture, see Skeggs, Wood and Thumim, 2008).

By contrast, a different mediation of the notion of the labour involved in 'making good' on 'reality' TV is apparent in the Brockley focus group, whose participants were black and white working-class. The value of participating on 'reality' television is discussed, but as a way of escaping the difficulties of providing for a family within economic constraints; escaping from being a 'ghetto rat' whilst at the same time 'keeping real'. Here the discussion focuses upon another white working-class woman - Jade Goody - who became famous for the vicious attacks made on her by The Sun tabloid newspaper ${ }^{7}$. The debates around Goody were based on her perceived lack of propriety: her colloquial direct speech, her size, her lack of education and her humour on the third series of Big Brother. ${ }^{8}$

Sonia: Don't get her started about Jade.

Ruby: I kind of like Jade. I kind of like Jade. My little ghetto rat made good, you know what I mean [laughter]. I like her.

Sally Mc: $\quad[\ldots]$ This is what it's done for a lot, the ghetto rats that you're all referring to.

Sally: I like Jade.

Sally Mc: About giving them a chance?

Ruby: Before you're struggling, ducking and diving, and then you get an opportunity through 'reality' TV and then all of a sudden you're able to provide for yourself, provide for your family and not go to bed and... you know what I mean...And not wake up in the morning and think, "Oh God, where is this going to come from, where am I going to get that from?" Reality TV does that.

Sally: Yeah.

Janet: No, I like Jade.

Marian: I do actually.

Ruby: It's only Jade that I like. I think she's done very well.

Marian: $\quad$ She does her own shows.

Sally Mc: $\quad$ But she does what she did well.

Sally: Yeah.

Ruby: Because there are some programmes, I mean how could you ..., you did, I don't like you so I don't care. But that's the first, I got to care about, like with Jade I liked her.

Sally: $\quad$ Yeah I like Jade. I do like her.

The connection to Jade is made through an ethic of care, to her proximity to the culture and labour of the group. That Ruby, Sally Mc and Sally are black perhaps produces the particular articulation of 'ghetto rats', but it is also through a shared sense of identification with class and labour. Jade's actual labour is valued and her participation on 'reality' television opens up an opportunity structure, with the possibility of not having to worry constantly about providing for your family. The stressed repetition of 'I like her' from all the focus group participants signals an insistence against the negative value generally attributed to Jade and those like her who are often positioned as the abject working class (see Skeggs, 2004). Here the 
group offers a display of defence against the judgement of her/their culture and labour as bad, and the fact that Jade has resolutely refused to accept and perform middle-class standards:

Marian: $\quad$ Yeah, she's all right. I don't know her but I mean [all talking at once]. She's done well [all talking at once]

Sonia: I suppose we all relate to that don't we?

Sally: With elocution lessons, she's not Jade.

Ruby: Yeah.

Sarah: She's still Jade.

Ruby: I say I like her, she's still got a belly, she's my kind of girl [laughter].

Marian: She has no poshness or no airs and graces.

The fact that they assess Jade's success - 'she's done well' - as a good thing, rather than critiquing her lack of skills, education or qualifications, suggests the Brockley group are bringing a different value system to bear about the composite of the 'authentic' person who also needs to provide. To our working-class groups it is precisely both Jordan and Jade's resistance to certain middle-class forms of transformation that gives them value. Both represent that which is devalued on television and dominant culture more generally: loud, excessive, sexual, large, fecund, local, uncompromising, and without pretensions. Both come from similar economic and cultural positions to the women in the group. Both are seen to be deserving of their success because they were not ashamed of, or apologetic of, their culture.

Applauding unpretentiousness is an older traditional of diffusing middle-class values and authority that is identified in Victorian Music Hall performances by Vicinus (1974) and continued to the present day in some television, music and film (Skeggs 2004). The different value systems and related authorisations that accompany social positions therefore obviously mediate relationships to television. The performance and endurance of labour have long been major values in working class lives, just as critiques of anti-pretentiousness have structured the challenges to the attempted imposition of middle-class standards and values. We should not be surprised therefore that 'reality' television is continuing to generate similar challenges to bourgeois intervention.

\section{'Looking through' - presence and the priority of care}

Whilst the focus groups tended to reify discussions of labour into groups readings, individual interviews and the text-in-action sessions allowed more intricate explorations of how emotional reactions are generated in all our viewers. Responses were articulated through the experiential resources viewers have to hand to make assessments of the different forms of labour on TV, and these were unsurprisingly worked through the competing and contradictory forces of class and gender. For example, we have argued that Lucy from our middle class group is assessing the incompatibility between forms of aesthetic labour and her own experience of mothering; members of our working class groups privilege material labour as a mode of authenticity; and it is the experience of material labour, or the value placed on educational labour, which defines the class differences in the group readings of reality TV participants' financial success. Our findings therefore do not paint a picture of working-class women as necessarily more sympathetic, and middle-class women as more condemnatory, towards television participants simply by virtue of proximity. For example, some of our working-class women quite forcefully took the high moral ground afforded to them as non-working mothers by privileging care for children, whilst watching Wife Swap (a reality show where two families often from starkly 
different social backgrounds swap wives). There were also often quite lengthy attempts made by the middle-class women to reach for a point of connection beyond that which might be obvious, in order to care for, and about, television participants.

Our final discussion explores one of these occasions further in order to draw out some of the workings of these forms of connection. The following extract is taken from a text-in-action session with Liselle (from our Forest Hill middle class group) while watching an episode of Wife Swap. It shows how even when the participants are viewed as a source of shock and humour to our viewer, and are clearly presented as extremely dysfunctional, she is able to 'look through' the symbolic representation of the person to analyse and value the relationship on display. In this instance, the television participants are a fat, white working class couple who constantly swear loudly, whose children behave badly, and who express their aversion to mixed race marriages. They are swapped with a healthy, fit, semi respectable black family. ${ }^{9}$ Yet when Liselle gets over her shock of their initial presentation she finds something endearing in their relationship:

\begin{tabular}{|c|c|c|}
\hline Audio-cue & Television text & Participant comments \\
\hline 05:31 & $\begin{array}{l}\text { Voice over: After } 18 \text { years of } \\
\text { marriage ... }\end{array}$ & $\begin{array}{l}\text { Liselle: Aaah. } \\
\text { [laughs] }\end{array}$ \\
\hline $05: 46$ & $\begin{array}{l}\text { Voice over: She definitely } \\
\text { wears the trousers, so to } \\
\text { speak. }\end{array}$ & Aaah. \\
\hline 05:59 & $\begin{array}{l}\text { Man: I wouldn't change her for } \\
\text { the world. }\end{array}$ & Aaah. \\
\hline $06: 12$ & $\begin{array}{l}\text { Man: ... she took me as I was, I } \\
\text { took her as she was. }\end{array}$ & $\begin{array}{l}\text { Aaah, oh my God. } \\
\text { [laughs] }\end{array}$ \\
\hline $06: 29$ & Woman: ...bubbly like David .. & \\
\hline 06.47 & $\begin{array}{l}\text {..Voice over describing other } \\
\text { family whilst focusing on the } \\
\text { fat couple eating large dinners } \\
\text { in front of the television }\end{array}$ & $\begin{array}{l}\text { Oh my goodness. } \\
\text { What a picture, that is phenomenal. } \\
\text { That is a performance that is } \\
\text { amazing } \\
\text { That is two fat people with a huge } \\
\text { amount of food } \\
\text { [laughs] } \\
\text { Oh my God. }\end{array}$ \\
\hline 08.11 & $\begin{array}{l}\text { Voice over: It is the day of the } \\
\text { swap. The couples hope that } \\
\text { the swapping..... }\end{array}$ & $\begin{array}{l}\text { I think what is nice about it is } \\
\text { that...yeah we can laugh at them, } \\
\text { but there is actually...there is } \\
\text { something very genuine between } \\
\text { them }\end{array}$ \\
\hline 9.08 & $\begin{array}{l}\text { Man: ...I will have a big } \\
\text { problem }\end{array}$ & $\begin{array}{l}\text { Did she say if they are black I will } \\
\text { have a big problem?! }\end{array}$ \\
\hline 09.15 & $\begin{array}{l}\text { Man: I am not against coloured } \\
\text { people }\end{array}$ & Oh my God. \\
\hline 09.23 & $\begin{array}{l}\text {...but I don't believe in black } \\
\text { and white together }\end{array}$ & Aaagh. \\
\hline \multicolumn{3}{|c|}{$\begin{array}{l}\text { Liselle moves in and out of different judging positions, firstly attributing value to the } \\
\text { relationship even though everything about the couple has been negatively coded, } \\
\text { then displaying shock at the racism expressed. She challenges the bad language } \\
\text { and rudeness of the older daughter towards the father. She is critical of the } \\
\text { manipulation of the swapped wife and of the programme format itself while reading } \\
\text { the husband/father's attempt to wield family power as a product of manipulation: }\end{array}$} \\
\hline
\end{tabular}




\begin{tabular}{|c|c|c|}
\hline $49: 35$ & $\begin{array}{l}\text { Dad: I've had enough of Mary's } \\
\text { [daughter] language. I told you } \\
\text { long before Christmas I have } \\
\text { had enough of Mary's } \\
\text { language. }\end{array}$ & Mmm. \\
\hline $50: 00$ & $\begin{array}{l}\text { Dad: Things have to change } \\
\text { round here }\end{array}$ & Ohhhhh! \\
\hline $50: 12$ & & $\begin{array}{l}\text { Jesus Christ! He has been } \\
\text { manipulated so much by her. }\end{array}$ \\
\hline $50: 22$ & $\begin{array}{l}\text { Dad: I am asking you [to wife] } \\
\text { to support me and back me ... }\end{array}$ & Wow. \\
\hline $50: 42$ & $\begin{array}{l}\text { Wife/Mum: } 18 \text { years down the } \\
\text { Swannee. Go for it. }\end{array}$ & $\begin{array}{l}\text { Wow. } \\
\text { They were so together at the } \\
\text { beginning. Look at how together they } \\
\text { were. } \\
\text { Oh my God. } \\
\text { Oh God. }\end{array}$ \\
\hline
\end{tabular}

Liselle sees how the apparatus of the television 'set-up' provoked the destruction of their relationship. Before condemning the family, through which it seems only entirely possible due to the way in which they have been represented, she reaches for a point of connection by evoking memories of her similar experiences and considering herself within a similar social dynamic:

But then again if I look at my family going 'bloody hell' that is the other thing, you can relate to it as well because I remember things like that you know, you know...I mean I can really relate to the girl who was manipulated by the black woman, because you just want to please the adults. (Liselle, Forest Hill)

Drawing upon the work of Vivian Sobchack, we might refer to these instances of evocation, where viewers conjure a 'presence' in the text, as 'constitutive actualisations'. This phrase comes from her discussion of the distinction between watching documentary and home videos. Documentary consciousness requires comprehension and learning, whereas home video requires the viewer to look through image via the experiential evocation of memory. In this process the images on the screen come to mean so much more than their object, they activate the viewer's sense of the whole person (constitutive) in the present (actuality). One might argue that reality TV occupies a curious space between documentary and home video and that its particular verisimilitude and construction of intimacy and immediacy generates recognition in viewers beyond that available in traditional documentary forms.

Such moments we would argue reveal a circuitous movement in and out of issues of 'value' where viewers make attempts at attachments with reality TV participants. Liselle 'sees through' the negative images of the couple and the manipulative elements of the programme format to contextualise and make the connections to her life, which is actually radically different in terms of class background. ${ }^{10}$ In this instance it is the verisimilitude of the unfolding relationships (mother, father, daughter, wife, husband) that generates the type of connections she has to 'reality' television. Liselle is alert to how the different couples have been stereotypically valued and positioned and even repeats the positioning, but rather than judging and legitimating the stereotype, she instead judges the quality of the relationships. 
Liselle evokes a 'presence' in the text which we might say is achieved through the structure of immanence made available in 'reality' television, which we can also see at work in some of our earlier examples. What is consistent across our findings is that viewers, by putting themselves in the place of participants, work to recognise the performances of domestic, material, feminine and relationship labour that are part of their own experience. The 'circuit of value' therefore means that in order to judge, you also have to care, and in order to care you need to have 'been there'.

\section{Conclusion}

By contributing to a new sense of 'presentness', as Kavka and West (2004) propose, the immediacy and domestic verisimilitude of 'reality' television enables moments of connectedness, which involve both judgement and self-placement. Through the display of domestic and emotional labour 'reality' television becomes emblematic of the Fourth shift, whereby affect and emotional labour become requirements to display value and governance in and of oneself. Yet the increased visibility of domestic and emotional labour follows in a long tradition of attempts to impose bourgeois standards of domesticity and self-governance on the working class. The formulae of 'responsibility given and yet surveillance required' has just found a new outlet and new techniques. That this new outlet for displaying and deriding workingclass women enables others to benefit from the display, by converting the imperative to improve into television careers and shareholder capital11 should come as no surprise as capital moves its line of flight to extract profit from wherever it can.

But what we think is interesting from our empirical research is the various ways our participants make their connections to the television participants through these circuits of value. They see through the 'transformation' narrative of the experts to the labour required, they reject the symbolic violence that is done to participants, whilst simultaneously participating in the assessment of the labour performed, because they too are located in that circuit of judgment. They are not extracting capital from the performance but locating themselves as fellow labourers, it is a collective enterprise. When Hartley (2004) proposes that television now makes the intimate "I" into a public property to be judged by strangers, we answer 'yes'... but: the intimate 'l' is always dialogical, always explored through social relationships. And this is what we saw in our responses: our viewers watched and judged and were watched and judged through their relationships to others, through an ethic of care. As Williams (2001) contends:

[C]are provides an important lens through which to make situated judgement about collective commitments and individual responsibilities. In this way it is different from liberal notions of justice, which are based upon legalistic principles that assume individuals are independent and atomistic beings. Instead it recognises us as all interdependent and as having the potential and responsibility to be cared for (p.478)

What surprised us from our research was how connections were made through viewer's positions in relationships (be it mothers, wives, partners) and how 'constitutive actualisations' were read through and/or back onto the relationships to moderate judgement. Knowing how reality television is designed to present morality in a particular way, viewers instead decide what matters; showing us the difference between our textual and empirical analysis. Through their immanent relationship to this mode of programming our participants defend against derision, assess labour contributions, continue the de-authorisation of middle-class standards, search for redeemable features, value non-transformation and pursue care. Against the almost wholesale denigration of the working class on reality television, always in need of 
transformation, our viewers see something quite different. Our textual analysis produced severe pessimism of the intellect; our empirical analysis provides optimism for the will.

\section{References}

Berlant, L. (2000) Intimacy: A special issue. Intimacy. L. Berlant (ed) Chicago: University of Chicago Press.

Biressi, A and Nunn, H (2005) Reality TV: Realism and Revelation London and New York, Wallflower Press.

Clough, P. (2003) "Affect and Control: Rethinking the body, 'beyond sex and gender'." Feminist Theory 4 (3): 359-664.

Couldry, N. (2007) Reality TV or the Secret Theatre of Neo-liberalism Review of Education Pedagogy and Cultural Studies.

David. M. (198) The State, The Family and Education London, Routledge and Kegan Paul.

Davidoff, L. and C. Hall (1987) Family Fortunes London, Hutchinson

Fleisch. W (1987) "Proximity and Power: Shakespearean and Cinemantic Space" Theatre Journal 4: 277-93.

Dovey, J. (2000) Freakshow: First Person Media and Factual Television London: Pluto Press.

Engel Manga, Julie (2003) Talking Trash: The Cultural Politics of Daytime TV talk shows New York: New York University Press.

Glucksmann, M. (2005) "Shifting Boundaries and Interconnections: Extending the 'Total Social Organisation of Labour' Sociological Review

Haralovich, M-B (1992) 'Sit-coms and Suburbs: Positioning the 1950's Homemaker' Private Screenings: Television and the Female Consumer L. Spigel and D. Mann. Minneapolis, University of Minnesota: 110-141.

Hartley, J (2004) "Kiss Me Kat": Shakespeare, Big Brother and the Taming of the Shrew Reality TV: Re-making Television Culture L. Ouellette and S, Murray (eds) New York and London, New York University Press: 303-323.

Hill, A. (2005) Reality TV: Audiences and Popular Factual Television London and New York: Routledge

Illouz, E (1997)"Who will care for the caretakers daughter? Towards a Sociology of Happiness in the era of Reflexive Modernity Theory, Culture and Society 14 (4): 3166.

Jokinen, E. (2008) Home and Work in the Fourth Shift. Home at Work: Dwelling Moving Belonging $\mathrm{H}$. Johansson and K. Saarikangas. Helsinki, SKS (Finnish Literature Society)

Jones, J. (2003) 'Show Your Real Face’ New Media and Society 5(3): 400-421. 
Hobson, Dorothy. (1982) Crossroads - The Drama of a Soap Opera. London: Methuen.

Hobson, Dorothy (1991) 'Soap Operas at Work' In Seiter, Ellen. et.al. (eds.) Remote Control: Television, Audiences and Cultural Power London and New York:

Routledge, pp. 150-167.

Hochschild, A (1983) The Managed Heart: The Commercialisation of Feeling Berkeley, Los Angeles, University of California Press.

Holmes, S and Jermyn, D (2004) 'Introduction: Understanding Reality TV' In Holmes, $S$ and Jermyn, D (eds.) Understanding Reality Television Routledge, London and New York.

Liebes, Tamar and Katz, Elihu (1990) The Export of Meaning Oxford, Oxford University Press

Livingstone, S (1990) Making Sense of Television London and New York: Routledge. Kavka, M and A. West (2004) Temporalities of the Real: Conceptualising Time Reality TV Understanding Reality Television. S. Holmes and D. Jermyn. London: Routledge: 16-153.

Lewis, J. (2004) The Meaning of Real Life. Reality TV: Re-making Television Culture L. Ouellette and S. Murray. New York and London. New York University Press: 288303.

Livingstone, Sonia. (1994) 'Watching Talk: Gender and Engagement in the Viewing of Audience Discussion Programmes'. Media, Culture and Society, 16, pp.429-447. Marx, K. (1973) Grundrisse London, Allen Lane/ NLR.

Press, A (1991) Women Watching Television: Gender, Class and Generation in the American Television Experience Philadelphia, University of Philadelphia Press.

Savage, M (2003) 'A New Class Paradigm? Review Article' British Journal of Sociology of Education 24 (4): 535-41.

Scannell, P. (2001) “Authenticity and Experience” Discourse Studies 3 (4): 405-411.

Skeggs, B. (2004) Class, Self, Culture London: Routledge.

Skeggs, B, Wood, H and Thumim, N (2008) 'Oh Goodness, I am watching reality TV: How methods make class in audience research' In European Journal of Cultural Studies 11 (1): 5-24.

Sobchack, V (1992) The Address of the Eye: A Phenomenology of Film Experience Princeton University Press.

Sobchack, V. (1999) "Towards a Phenomenology of Nonfictional Film Experience" Collecting Visible Evidence J. Gains and M. Renow. Minneapolis, Minnesota, Minnesota University Press. 241- 254.

Strathern. M (1992) After Nature: English Kinship in the Late Twentieth Century Cambridge, Cambridge University Press. 
Vicinus, M. (1974) The Industrial Muse: A Study of Nineteenth Century British working Class Literature London: Croom Helm.

Walkerdine, V. (2003) 'Reclassifying Upward Mobility: Femininity and the Neo-Liberal Subject', Gender and Education. 15 (3): 237- 48.

Williams, F. (2001) "In and Beyond New Labour: Towards and New Political Ethics of Care" Critical Social Policy 21(4): 467-493.

Willis, P (1977) Learning to Labour: How Working Class Kids Get Working Class Jobs Farnborough, Hants, Saxon House.

Wood, H and Skeggs, B (2008) 'Spectacular Morality: Reality television, individualisation and the re-making of the working class' in Hesmondhalgh, D and Toynbee, J. (eds.) The Media and Social Theory London and New York, Routledge.

Wood, H. Skeggs, B and Thumim, N (2008) 'It's just sad: Affect, Judgement and Emotional Labour in reality TV viewing' in Hollows, J. and Gillis, S. (ed.) Homefires: Domesticity, feminism and popular culture. Routledge.

Wood, H (2007) 'The Mediated Conversational Floor': An interactive approach to audience reception analysis' Media, Culture and Society 29 (1): 75-103.

Wood, H. (2008) Talking With Television Urbana: University of Illinois Press.

\footnotetext{
${ }^{1}$ Hardt and Negri's definition of affective labour is that which 'always directly constructs a relationship' (2004: 147). However, the gender-specific aspects of these 'new' forms of immaterial labour are rarely addressed.

${ }^{2}$ Which is a reversal for the discursive term 'economy', which was initially used to describe domestic management: see Poovey.

${ }^{3}$ Selected from British terrestrial television these shows included: Wife Swap (RDF for Channel 4 2003-), Faking It (RDF for Channel 4 2000-), What the Butler Saw (BBC2 2004), Get a New Life (BBC Scotland 2003-), The Apprentice (RTL Talkback Thames 2005-), What Not to Wear (BBC 2001-), Supernanny (Ricochet for Channel 42004 -), Ladette to Lady (RDF for ITV 2005-), and Club Reps (SMG for ITV 2004-). We classified programmes into themes (money, holidays/travel, homes, food and health, hygiene, families/relationships, work, sex, appearance, manners, class mobility) that we mapped against 'dramatic techniques' (swaps, passing, challenges, competition, make-over, expert observation, life overhaul, abject).

${ }^{4}$ The focus of our textual analysis detailed how a 'moral person economy' was made visible on 'reality' television through a process of metonymic morality. Here we describe how types of behaviour and dispositions (e.g. eating, speaking, manners, tastes, forms of expressions) are identified as parts which are loaded with moral value (good or bad, potential or abject) and outlined as in need of improvement in order to transform the whole self (see Wood and Skeggs, 2008).

${ }^{5}$ Jordan, aka Katie Price, is a British celebrity famous for her enormous breasts, relationships with footballers, her marriage to pop singer Peter Andre, and looking after her handicapped child.

6 'Wife Swap Star Guilty of Benefit Fraud' : 'The loudmouth mother of eight, who shot to fame in a hit Channel 4 reality show, pocketed $£ 3,800$ for media work while raking in $£ 37,500$ a year in state handouts' Daily Mail $26^{\text {th }}$ September, 2005.

7 'By the end of the summer Jade had been described as a nasty slapper, public enemy number one, the most hated woman in Britain and a monster', see 'The Jade Good Phenomenon' in The Independent $9^{\text {th }}$ January 2007

(http://www.independent.co.uk/news/people/the-jade-goody-phenomenon-431370.html access 21/04/08).
} 


\footnotetext{
${ }^{8}$ This focus group discussion took place before Jade was ejected from Celebrity Big Brother for attacking Indian film star Shilpa Shetty by calling her 'Shilpa Poppadom' and creating a national scandal during which the then Chancellor (now Prime-Minister, Gordon Brown) had to apologise for Jade and British racism to the Indian Prime-Minister. See full transcript on http://newsvote.bbc.co.uk/mpapps/pagetools/print/news.bbc.co.uk/1/hi/enertainment. Downloaded on 15.08.07).

${ }^{9}$ We add the prefix semi here because we are told that Vince, the husband, spends $£ 50$ per week on weed.

${ }^{10}$ Liselle directly identifies herself as 'middle-class' through a discussion of her education, housing, family and aspirations.

${ }^{11}$ RDF who make Wife Swap announced a turnover of $£ 37.5 \mathrm{~m}$ and profits of $£ 11.5 \mathrm{~m}$ in 2006 (http://www.rdfmedia.com/rdfmedia/rns/.rnsitem?id=1161237679nRHSS691k\&t-popup accessed 21/4/08).
} 